\title{
GENERAL FEATURES OF THE ECOLOGY AND BIOGEOGRAPHY OF TASMANIAN SUBTIDAL ROCKY SHORE COMMUNITIES
}

\author{
by G.J. Edgar \\ Department of Zoology, University of Tasmania \\ (with two tables, four text-figures and one plate)
}

\section{ABSTRACT}

EDGAR, G.J., 1984 (31 viii): General features of the ecology and biogeography of Tasmanian subtidal rocky shore communities. Pap. Proc. R. Soc. Täsm., 118: 173-186, pl. 1.

https://doi.org/10.26749/rstpp.118.173 ISSN 0080-4703. Department of Zoology, University of Tasmania, Hobart, Tasmania, Australia, now C.S.I.R.O., P.O. Box 20, North Beach, Western Australia.

A number of subtidal benthic assemblages of plants and animals which commonly occur around the Tasmanian coast are described. These assemblages are incorporated into a general scheme which relates subtidal zonation patterns to wave exposure and depth.

The existence of a cool-temperate marine biogeographic province (the Maugean), centred in southern, western and eastern Tasmanian waters, is reaffirmed. The biota of the northern Tasmanian coast is considered similar to that of the Victorian coast and includes a large component of Flindersian (Southern Australian) species. A number of Peronian (New South Wales) species reach the Tasmanian east coast. Most of these animals probably drift to Tasmania as pelagic larvae in southward flowing currents, and may even travel further afield to New Zealand, but have difficulty surviving to maturity and spawning. Many Maugean plant and animal species also occur in New Zealand.

\section{INTRODUCTION}

A considerable number of studies describing Tasmanian intertidal communities have been reported, notably by Guiler (1952a,b, 1954), Guiler et al. (1958), Bennett \& Pope (1960), King (1973) and Saenger (1974). By comparison the sublittoral zone has been poorly investigated, despite the widespread availability of SCUBA equipment during the past 20 years. Four algal studies conducted in South Australia (Shepherd \& Womersley 1970 , 1971, 1976, 1981) represent the only comprehensive ecological studies of subtidal reef habitats in southern Australia. Within the Tasmanian region, published accounts of sublittoral communities are limited to descriptions of benthic algal assemblages in the Port Arthur (Cribb 1954) and D'Entrecasteaux Channel (Edgar 1983a,b) regions, an investigation of the ecology of fishes in soft-bottom habitats (Last 1983), and a descriptive survey of the species of macroalgae and fish which were present at several potential marine park sites around the coast (Edgar 1981). During the course of the latter study, as well as associated surveys carried out since that time, a limited number of assemblages of marine organisms were noticed to recur around the Tasmanian coast. Consequently, a description of these assemblages is published here to allow future studies at particular localities to be related to the overall situation, and to provide a general framework which can then be tested and modified.

A second aim of the present study was to clarify the biogeographic status of the Tasmanian marine biota. The degree of "distinctiveness" of this biota has been the subject of considerable dispute by mainland workers since Iredale \& May (1916) proposed the idea of a Maugean biogeographic province centred on the southeast Tasmanian coast. Amongst more recent workers, Bennett \& Pope (1960) argued that a separate cool-temperate marine province was well defined in Victoria and Tasmania. Conversely, Womersley \& Edmonds (1958) considered that any differences between the Tasmanian and South Australian marine ecosystems are minor and hence the two regions belong to the one biogeographic province. In a later review Womersley (1981) nevertheless noted "whether one province (the Flindersian) is recognized for the whole of southern Australia and Tasmania and whether the south-eastern region 
is recognized as a province (the Maugean) or only as a subprovince, depends on what emphasis is placed on a few conspicuous organisms (for example Durvizzaea, Macrocystis) compared to the whole flora and fauna". Although discussions of biogeographic regions necessarily depend on individual definitions and consequently can be confused, the identification of rapid geographical changes in flora and fauna is nevertheless important both as evidence of present biogeographical barriers and as an indication of past biogeographical processes.

\section{ENVIRONMENTAL CONDITIONS}

\section{Hydrology}

Mean surface sea temperatures off southeastern Tasmania vary from about $12^{\circ} \mathrm{C}$ in August to about $17^{\circ} \mathrm{C}$ in February (Edwards 1979). Temperatures in Bass Strait are generally about $2^{\circ} \mathrm{C}$ warmer. Conditions inshore are much more dependent on local atmospheric conditions. Temperatures within shallow bays usually vary from about $8^{\circ} \mathrm{C}$ in winter to about $22^{\circ} \mathrm{C}$ in summer, and can decline as 1 ow as $2{ }^{\circ} \mathrm{C}$ and rise above $27^{\circ} \mathrm{C}$ (Thomson et al. 1982).

The salinities of coastal waters are relatively constant during the year, varying from about $35.1 \%$ to about $35.4 \%$ (Edwards 1979). The levels of nutrients in Tasmanian seas are poorly known (Rochford 1974, 1979) but are unlikely to decline sufficiently to limit the growth of inshore marine life.

\section{Currents}

Marine waters along the eastern Tasmanian coast flow southward under the influence of the East Australian Current. Warm core eddies, which break from East Australian Current meanders, may oceasionally reach inshore Tasmanian waters. These discrete water bodies are about $3^{\circ} \mathrm{C}$ warmer than surrounding seas and generally move southward from the southern New South Wales coast and then eastward towards New Zealand (Ni1sson \& Cresswe11 1981).

Currents along the Tasmanian west coast were thought by Newel1 (1960) to flow in a northeasterly direction during the summer months and then reverse direction to flow southeastward during winter. However, Baines et al. (1983) described a west coast current, named the Zeehan Current, which varied seasonally in strength but flowed southward throughout the year.

Tidal standing waves located at the east and west entrances to Bass Strait were postulated by Pollock (1971) to restrict the movement of surface water from the Bass Strait basin for a large part of the year. A cascade of deep saline water nevertheless flows from Bass Strait along the eastern Victorian coastline during winter months (Godfrey et al. 1980).

\section{Tides}

Mean tidal heights at selected localities around the Tasmanian coast, as listed in the Australian National Tide Tables (Dept of Defence 1977), are shown in table 1. Tidal ranges are relatively large (exceeding $2.5 \mathrm{~m}$ ) in western Bass Strait but decline to $2.0 \mathrm{~m}$ in eastern Bass Strait and are less than a metre in most other areas of the State. The meteorological influences on sea level changes along the microtidal southern and western coasts may be equal to the solar and lunar influences (Matthews 1978).

\section{Sea State}

Bennett \& Pope (1960) and Davies (1978) discussed the exposure of different Tasmanian coasts to wind and waves. The exposure classification scheme described by Bennett \& Pope (1960) is used in the present study. Using this scheme, reefs on the west coast with direct wave action are classed as maximally exposed and those on the east coast as submaximally to maximally exposed. The northern Tasmanian shore is generally classed as a sheltered open coast, however a few reefs in southwestern and southeastern Bass Strait with slightly greater wave exposure, such as Rocky Cape, are classed as moderately exposed. 


\section{G.J. Edgar}

TABLE 1

MEAN TIDAL HEIGHTS AT SELECTED TASMANIAN LOCALITIES. Data from Department of Defence (1977).

\begin{tabular}{lcccc} 
& \multicolumn{3}{c}{ Tidal Height } \\
& MHHW & MLHW & MHLW & MLLW \\
Grassy, King Island & 1.4 & 0.7 & 0.6 & 0.0 \\
Stanley & 3.6 & 3.0 & 1.3 & 0.8 \\
Georgetown & 3.1 & 3.1 & 1.0 & 0.6 \\
Winter Cove, Kent Group & 2.3 & 2.2 & 0.6 & 0.2 \\
Lady Barron, Flinders Island & 1.6 & 1.6 & 0.7 & 0.5 \\
Waterhouse Island & 2.3 & 2.2 & 0.6 & 0.2 \\
Swan Island & 1.6 & 1.4 & 0.5 & 0.2 \\
Hobart & 1.4 & 1.2 & 0.9 & 0.5 \\
Maatsuyker Island & 0.9 & 0.8 & 0.8 & 0.4 \\
Cape Sore11 & 0.9 & 0.8 & 0.7 & 0.4
\end{tabular}

METHODS

General information relating to the depth and distribution of macro-algae and fish was recorded on underwater notepads during SCUBA dives at various reefs around the northern, eastern and southern coasts of Tasmania, and the eastern Bass Strait islands (fig. 1). The western Tasmanian coast and King Island were not investigated.

The similarities in reef fish fauna between different sites were compared using Sorenson's similarity coefficient (Southwood 1966), which was calculated as follows

$$
\mathrm{S}=2 \mathrm{c} /(\mathrm{a}+\mathrm{b})
$$

where $a$ is the number of fish species sighted at location 1; b is the number of species sighted at location 2 ; and $c$ is the number of fish in common to the two locations.

Fish species generally found on sedimentary substrata, such as urolophids and platycephalids, and cryptic species, such as gobiids, clinids, tripterygiids and gobiesocids, were not considered in these analyses.

\section{RESULTS AND DISCUSSION}

Effects of Wave Exposure and Depth

Despite an overlap of species near the boundaries of different assemblages, the 1ocations of the major assemblages of benthic organisms along the eastern, southern and western Tasmanian coasts can be predicted reasonably accurately by reference to wave exposure and depth (fig. 2). The benthic assemblages in Bass Strait are less well defined but approximately follow the same classification. The dominant species of plants and animals within these assemblages are as follows:

\section{DurvizZaea Assemblage}

The sublittoral fringe and upper sublittoral zone on exposed coasts are colonized by monospecific stands of Durvizzaea potatorum (Labil1.) Aresch. (plate 1a). Xiphophora gladiata (Labi11.) Mont. ex Kje11, and to a lesser extent Lessonia cormgata Lucas, a1so occur in this zone. Xiphophora often forms a narrow band above the Durvizzaea belt, particularly in moderately exposed areas, and is also occasionally present at the interface between the Durvizzaea and Lessonia/PhyZZospora zones. It is likely that Xiphophora and other macroalgae are capable of growing at wave-swept sites but are outcompeted by Durvizzaea, presumably because the whiplash motion of Durvizzaea prevents the settlement and/or growth of the other algal species. This hypothesis, which contrasts with the situation in Chile where Santelices et al. (1980) found that Lessonia nigrescens outcompeted Durvizzaea antarctica, is supported by the fact that cleared patches within the Durvizzaea 


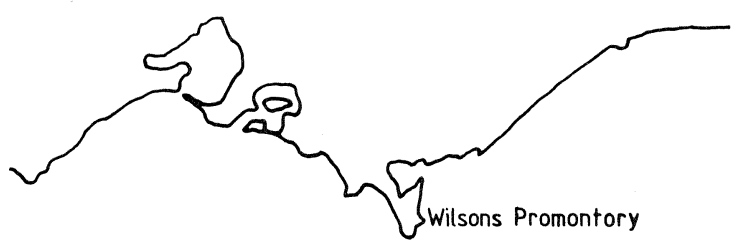

\{\}$_{\text {King Is. }}$

- Kent Group

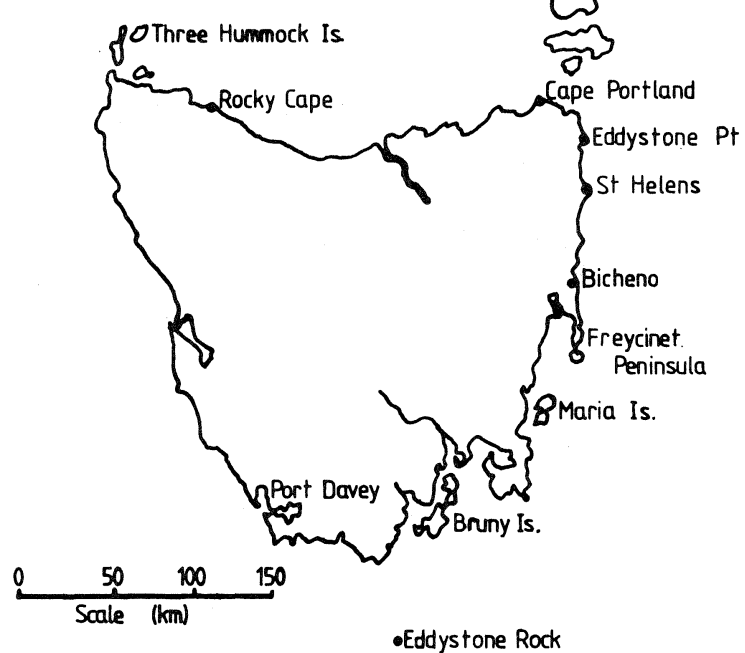

FIG. 1 - Map of Tasmania showing localities mentioned in the text.

the Durvizzaea zone (plate 1c). experiments are needed to deduce the factors result near-exclusion of one or the other of these species because it is difficult to predict which of the two species will be most conspicuous in any area. At Cape Queen Elizabeth on the exposed coast of Bruny Island, for example, Lessonia corrugata is the dominant algae at depths between 3 and 7 metres while PhyzZospora comosa is rare, however 30 $\mathrm{km}$ south at Cape Bruny PhyZZospora is the dominant species at similar depths. The two species, nevertheless, appear to differ slightly in some of their physical preferences; Lessonia preferring marginally shallower water, cooler water temperatures and a more steeply sloping rock substratum than PhyZZospora.

\section{EckZonia/Mixed Algal Assemblage}

The presence of EckZonia radiata plants is possibly the only unifying feature of this assemblage which is otherwise difficult to characterize because of the diversity of the flora. Ecklonia radiata is the dominant species below the Lessonia/Phylzospora assemblage in exposed regions (plate lb), but becomes a relatively minor constituent of a mixed algal assemblage in more sheltered habitats (with Acrocarpia paniculata (Turn.) Aresch., Seirococcus axillaris (R.Br.) Grev., Cystophora retorta (Mert.) J.Ag., Carpoglossum confluens (R.Br.) Kutz., Halopteris spp., Codium spp., Jeannerettia Zobata Hook. \& Harv., Plocamium angustum (J.Ag.) Hook. E Harv., Melanthalia obtusata (Labil1.) J.Ag., Phacelocarpus Labizlardieri (Mert.) J.Ag. and Hemineura frondosa Harv., and also Cystophora monilifera J.Ag., C. polycystidea Aresch., C. subfarcinata (Mert.) J.Ag., Macrocystis zone are colonized almost exclusively by Durvizzaea sporelings, prevented from settling or are less rapid colonizers. Moreover, sloping substrata where the plants experience little vertical frond Durviziaea zone on a gently sloping reef east of isolated Eddystone coast) extends to $18 \mathrm{~m}$ depth with individual plants occurring at $30 \mathrm{~m}$, while other large brown algae radiata (C.Ag) J.Ag., PhylZospora comosa C.Ag., Xiphophora gladiata and Macrocystis pyrifera (L.) C.Ag.) were also present but were resCystophora torulosa Assemblage Cystophora toruzosa (R.Br.) $\mathrm{J} . \mathrm{Ag}$. is the dominant plant in the lower eulittoral zone, and also fringe, in most areas with insufficient wave exposure for the growth Durvilzaea potatorum. A band of generally occurs above Cystophora torulosa, particularly in the more

\section{Lessonia/PhyZZospora Assemblage}

Either Lessonia corrugata or PhyzZospora comosa plants generally dominate the reef substratum below sheltered regions. 


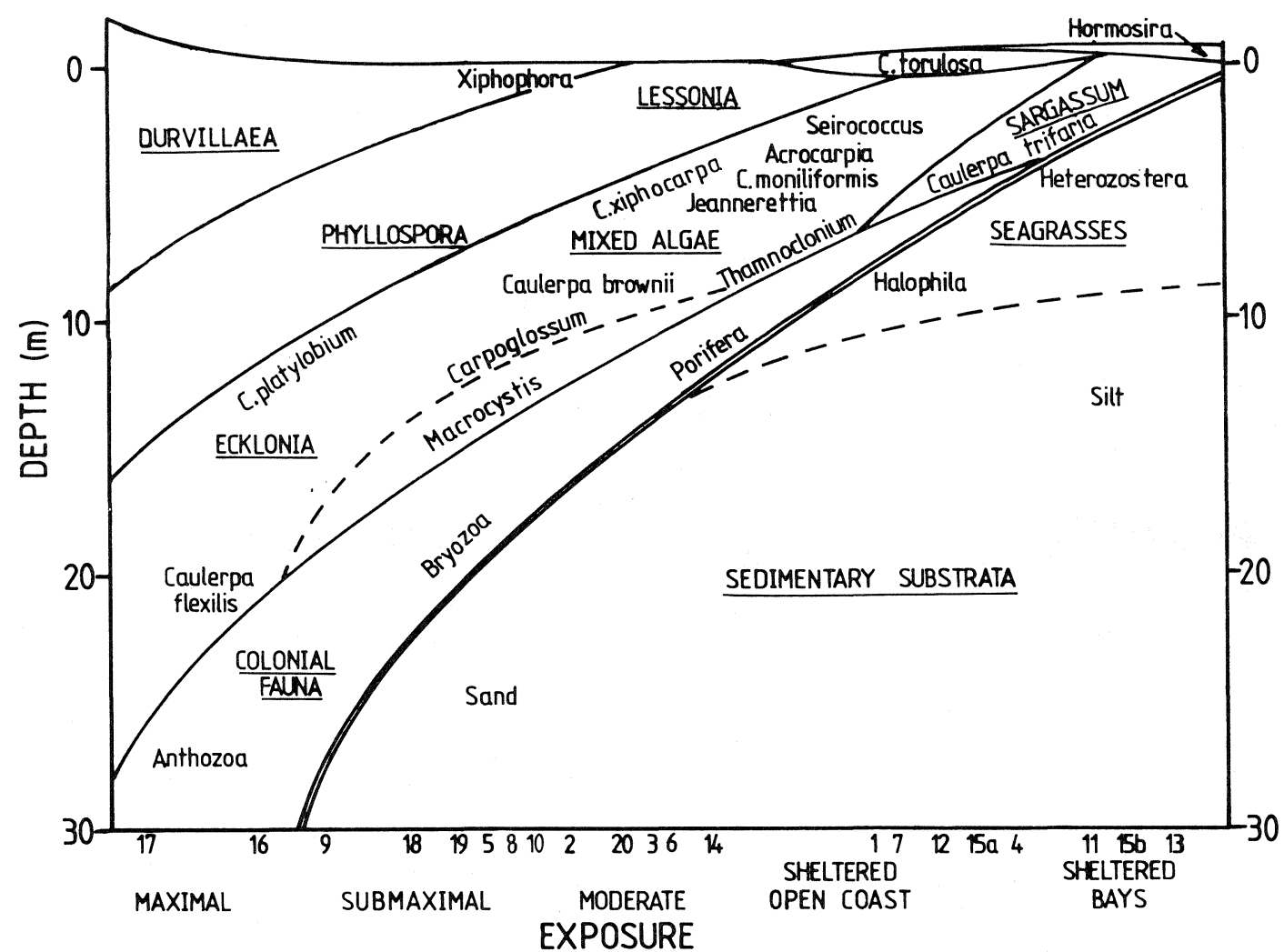

FIG. 2 - Generalized scheme showing the distribution of different benthic assemblages in Tasmania. The names of the conspicuous organisms are shown in the position of depth and exposure at which they are most abundant, however many of these species are found in other environmental conditions. The Phylzospora/Lessonia assemblage is incorporated within the Ecklonia/mixed algal assemblage in Bass Strait.

The wave exposure of the sites surveyed during this study are shown along the abscissa where Site 1 is Garden Cove, Deal Is., Kent Group; Site 2 is the southwestern point of Erith Is., Kent Group; Site 3 is Palana, Flinders Island; Site 4 is Tongue Point, F1inders Island; Site 5 is North West Cape, Three Hummock Is.; Site 6 is Rocky Cape; Site 7 is Cape Portland; Site 8 is Eddystone Point; Site 9 is Merrick Rocks near St Helens; Site 10 is Fossil Cliffs, Maria Is.; Site 11 is Encampment Cove, Maria Is.; Site 12 is Tinderbox, D'Entrecasteaux Channel; Site 13 is Woodbridge, D'Entrecasteaux Channel; Site 14 is Ninepin Point, D'Entrecasteaux Channel; Site 15a is a semi-exposed site and Site 15b a sheltered site, Fancy Point, Bruny Is. (Edgar 1983a,b); Site 16 is Cape Queen Elizabeth, Bruny Is.; Site 17 is Cape Bruny, Bruny Is.; Site 18 is Shoemaker Bay, South Coast; Site 19 is Maatsuyker Is.; Site 20 is Breaksea Is., Port Davey; and Site 21 is Eddystone Rock.

angustifolia Bory, Sargassum heteromorphum J.Ag. and Scaberia agardhii Grev. in Bass Strait). Most of the brown algal species in sheltered habitats extend only to moderately exposed coasts, while sheltered red algal species range further and also generally occur on maximally exposed coasts at the same depths as Ecklonia. A number of other codominant species belonging to the Ecklonia/mixed algal assemblage are most abundant in regions with particular environmental conditions (notably Caulerpa flexilis Lamaroux and Thamoclonium 

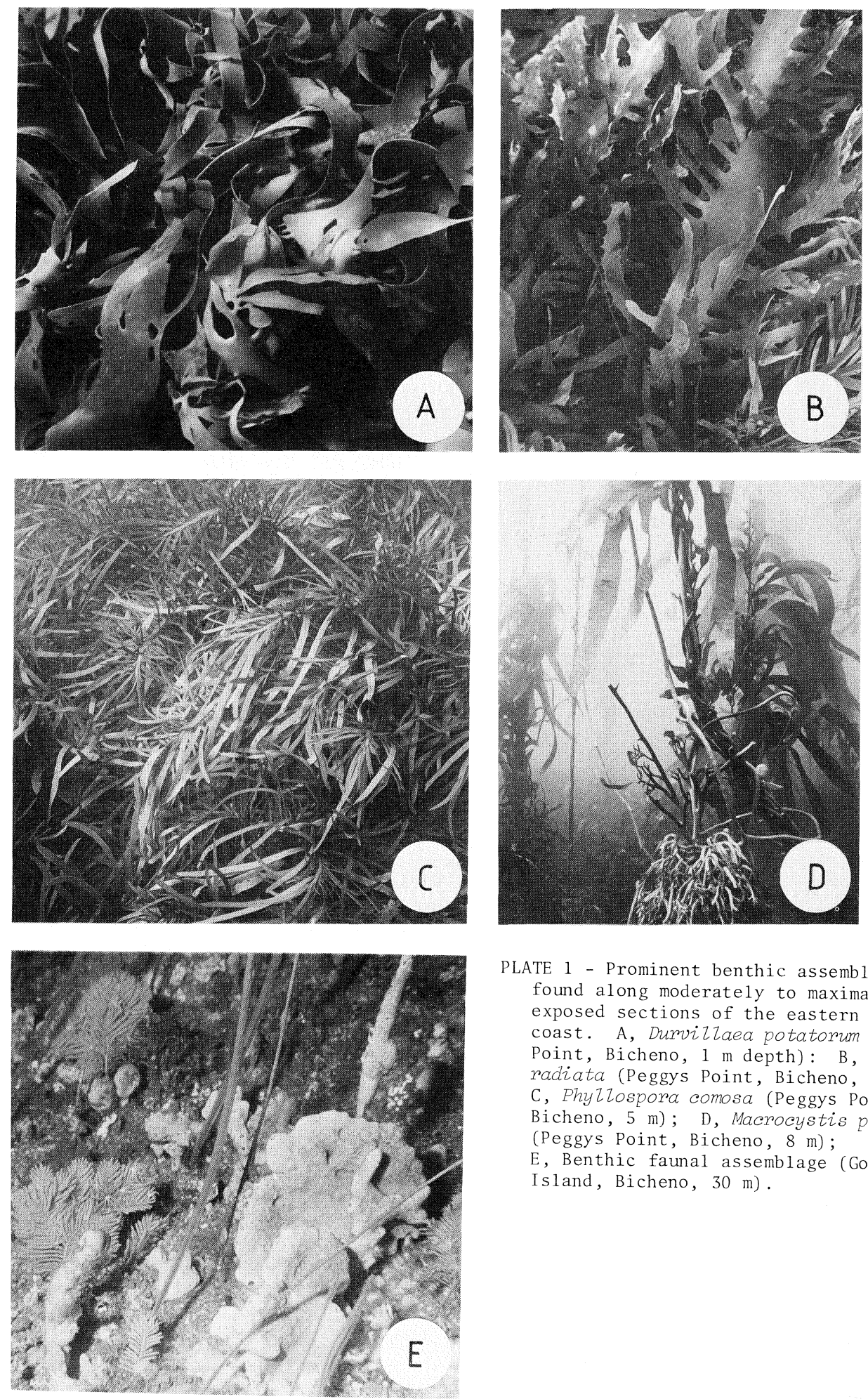

PLATE 1 - Prominent benthic assemblages found along moderately to maximally exposed sections of the eastern Tasmanian coast. A, Durvizlaea potatorum (Peggys Point, Bicheno, $1 \mathrm{~m}$ depth): B, Ecklonia radiata (Peggys Point, Bicheno, $7 \mathrm{~m}$ ); C, PhyZlospora comosa (Peggys Point, Bicheno, $5 \mathrm{~m})$; D, Macrocystis pyrifera (Peggys Point, Bicheno, $8 \mathrm{~m}$ );

E, Benthic faunal assemblage (Governor Island, Bicheno, $30 \mathrm{~m}$ ). 


\section{G.J. Edgar}

sp. in deeper water, Cystophora platylobium (Mert.) J.Ag. in maximally or submaximally exposed areas, C. xiphocarpa in moderately exposed, sand scoured areas, and Caulerpa brownii (C.Ag.) End1. on vertical or steeply sloping rock faces). Another locally common species, Macrocystis pyrifera, is dominant in depths of 8 to $22 \mathrm{~m}$ in submaximally or moderately exposed regions with horizontal substrata (p1ate 1d). Macrocystis fronds form a dense canopy which modifies the benthic algal community by shading the reef and consequently preventing large brown algae, other than an occasional Ecklonia plant, from growing. One further species of interest within the EckZonia/mixed algal assemblage is Cystophora moniliformis (Esper) Wom. which grows in a variety of physically stressed areas but appears to be outcompeted for space in more favourable habitats. C. moniliformis is most abundant on sand scoured reefs, including those covered by several centimetres of sediment (see Shepherd \& Womersley 1981), and in the sublittoral fringe below C. torulosa.

\section{Sargassum Assemblage}

This sheltered assemblage is characterized by the codominant Fucales Sargassum bracteolosum J.Ag., S. verrucolosum (Mert.) J.Ag., Cystophora retroflexa (Labill.) J.Ag. and Caulocystis cephalornithos (Labill.) Aresch. with small Zonaria turneriana J.Ag. plants also occurring in high densities but being relatively inconspicuous (Edgar 1983b). The rhizomatous green alga Caulerpa trifaria Harv. is often present with the deeper fucoid algae but is not restricted to the Sargassum assemblage because it also extends into the benthic faunal assemblage and is found at exposed locations in the Ecklonia/mixed algal assemblage. In Bass Strait waters Scaberia agardhii generally also occurs within the Sargassum assemblage, Sargassum bracteolosum and Cystophora retroflexa are not very conspicuous, and Caulocystis cephalomithos is often replaced by C. uvifera (C.Ag.) Aresch.

\section{Benthic Faunal Assemblage}

In sheltered, turbid conditions a benthic faunal community is present below the Sargassum assemblage, but has a low diversity because very few sedentary animal species survive amongst the fine sediment which coats the reefs (the sponge PhylZospongia caliciformis Carter being one exception). However, a diverse benthic animal assemblage of sponges, gorgonians (such as Mopsea whiteleggei Thomson \& Mackinnon, Acabaria sp. and Primnoella australasiae Gray), alcyonarians (including Capnella erecta Verseveldt), ascidians, bryozoans and hydroids is found in deeper, more exposed areas (plate le). A number of red algal species (e.g. Sonderopelta coriacea Wom. \& Sinkora and Thamnoclonium sp.) are found in the shallower sections of the benthic faunal assemblage. The minimum depth of this assemblage depends on the maximum depth at which fucoid and laminarian algal species grow and is thus primarily dependent on water clarity. In southern Tasmania at locations near the mouths of such rivers as the Huon, Old and Davey (e.g. Ninepin Point in D'Entrecasteaux Channel and Breaksea Island in Port Davey) the benthic faunal assemblage occurs at a much shallower depth than predicted in figure 2. At these sites a surface layer of darkly stained, tannin-rich, estuarine water greatly restricts light penetration to the fully marine waters at depth, particularly during the winter months. At Breaksea Island, for example, Durvilzaea potatorum extends to $2 \mathrm{~m}$, Phyllospora to $3 \mathrm{~m}$, the Ecklonial mixed algal assemblage to $5 \mathrm{~m}$, and then the benthic faunal assemblage to the edge of the reef at $16 \mathrm{~m}$ depth.

\section{Effects of Latitude}

The depth ranges of the Durvizlaea and Lessonia/PhyZZospora assemblages increase with latitude. The Durvilzaea zone at Merrick Rock near St Helens on the northeastern coast, for example, extends to a depth of on $1 \mathrm{y} 1 \mathrm{~m}$, whereas at places with similar exposure on the southern coast Durvilzaea is dominant to 3 or $4 \mathrm{~m}$ depth. As noted previously, $D$. potatorum is present at $30 \mathrm{~m}$ depth at Eddystone Rock off the south coast. Moreover, Durvillaea occurs in sheltered habitats in Port Davey (for example Bramble Cove) but is not found at moderately exposed locations on the Tasmanian north coast (for example Rocky Cape). Durvilzaea is also absent from the submaximally exposed coast of Deal Island, although it occurs at Wilsons Promontory, Victoria, and Palana, Flinders Island. Lessonia corrugata is not present on many Bass Strait reefs and PhyZZospora comosa plants often do not form a distinctive assemblage but occur within the Ecklonia/mixed algal assemblage. 
The fish fauna also varies with latitude. The number of fish species sighted during half-hour diving transects decreases significantly from Bass Strait to the east coast and southern Tasmania (fig. 3), presumably because many warm-temperate species cannot survive in the cool waters off the south coast.

\section{Biogeography}

The similarity matrix presented in figure 4 shows the degree of association between the reef ichthyofaunas at the Investigator Group (South Australia), Wilsons Promontory (Vic.), Avalon (N.S.W.) and different regions around Tasmania. A list of the fish species sighted during the study in the various Tasmanian regions is given in appendix 1 . Despite small sample sizes at Avalon and Wilsons Promontory, which tend to reduce the level of similarity, it appears that southern Tasmania, South Australia and New South Wales have markedly different reef fish assemblages. On the basis of these reef fish distributions, plus additional observations in Tasmania, it is useful to consider that a Maugean marine province exists and is centred in southern, western and eastern Tasmania. Bass Strait comprises an overlap area, primarily between Maugean and Flindersian (South Australian) species.

A large proportion of the Flindersian plants (e.g. Sargassum heteromorphum, Cystophora monilifera, C. polycystidea, C. botryocystis Sond., Scaberia agardhii and Posidonia australis Hook. f. Black) and animals (e.g. Meuschenia hippocrepis (Quoy \& Gaimard), M. flavolineata Hutchins, Platycephalus speculator Klunzinger, Aracana omata (Gray) and Parma victoriae (Günther)) are widespread in Bass Strait but are very rarely if ever found further south. The great reduction in Flindersian species from Bass Strait to the Tasmanian east coast, which causes very pronounced changes in the plant and animal assemblages over $25 \mathrm{~km}$ distance from Cape Portland to Cape Musselroe, is most 1ikely due to increased wave exposure and decreased water temperatures. This change in biota in northeastern Tasmania, and a similar change around the northwestern corner of Tasmania, is probably much greater than changes in marine communities over comparable distances at other biogeographical boundaries around the Australian coast. Nevertheless, several Flindersian species penetrate in reduced numbers along the east coast, and a large proportion of these reach Maria Island (for example the seagrass Amphibolis antarctica (Labill.) Sond. \& Asch. and the fishes Melambaphes zebra (Richardson), Olistops cyanomelas Richardson and Neoodax beddomei (Johnston)). It is notable that, as well as these Flindersian species, a number

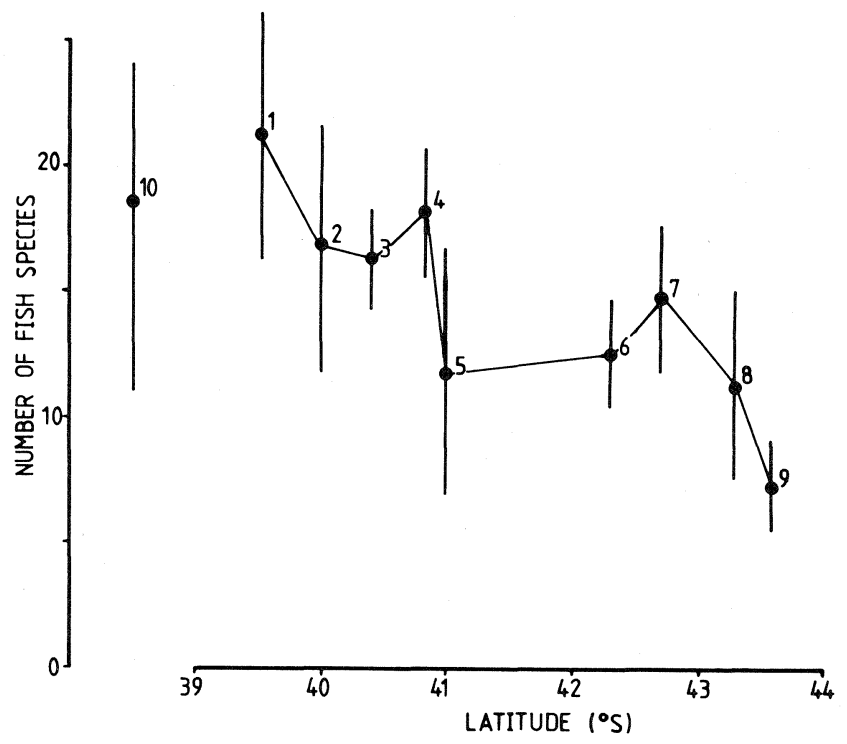

FIG. 3 - Relationship between latitude and the mean number

( \pm standard deviation) of fish species sighted during a halfhour diving period at moderately to submaximally exposed sites in different regions of Tasmania. Regions are as follows:

1 Kent Group

2 F1inders Island

3 Three Hummock Island

4 Rocky Cape

5 Northeast (Bicheno to Eddystone Point)

6 Freycinet Peninsula and Schouten Island

7 Maria Island

8 Bruny Island

9 South Coast

10 Investigator Group, South Australia. 
of species of planktonic crustacea (Nyan Taw 1975), infaunal cumacea (Dartnal1 1981) and Peronian (New South Wales) reef species (e.g. the fishes Girella elevata Macleay and Atypichthys strigatus (Günther) and the echinoid Centrostephanus rodgersii Agassiz), also are rare or absent south of approximately the latitude of Maria Island. Nyan Taw (1975) considered that this faunal boundary resulted from a change in hydrological conditions.

Peronian reef species are only conspicuous in Tasmania at the Kent Group, the southernmost site where the fishes Aptychotrema rostrata Shaw \& Nooder, Chromis hysilepis (Günther) and Opthalmolepis cyanogramma (Cuvier \& Valenciennes) have been recorded, and to a lesser extent the Furneaux Group, particularly the east coast of Flinders Island, and along the northeastern Tasmanian coast. A few species (e.g. Atypichthys strigatus and Parma microlepis Günther) also penetrate to western Bass Strait.

It is likely that few Peronian animals successfully spawn in Tasmanian waters and that the distribution and abundance of most Peronian species are dependent on the survival of pelagic larvae spawned in N.S.W. and the vagaries of the East Australian Current because (i) the number of species and individuals decreases markedly with increasing latitude, (ii) adult Peronian fish are numerically insignificant compared to juveniles, and (iii) the abundance of many Peronian animal species varies greatly from year to year (for example the recruitment of the rock lobster Jasus verreauxi (H. Milne-Edwards) at Flinders Island; and the prawn Penceus plebejus Hesse at North East River estuary, Flinders Island, and Georges Bay, northeastern Tasmania). Moreover, some Peronian species probably have become much more conspicuous in Tasmania over the past 20 years, during a period when sea temperatures along the eastern Tasmanian coast have risen (by an average of $1.5^{\circ} \mathrm{C}$ at Maria Island, Rochford 1981). The lower eulittoral barnacle Megabalanus nigrescens (Lamarck) appears to be one such species as it is now abundant at many places on the Tasmanian east coast including Eddystone Point and Eaglehawk Neck, while 24 years ago Bennett \& Pope (1960) considered that the species "fails to bridge the gap across Bass Strait" despite collecting intensively at those two east coast localities.

Most species with clear Maugean affinities are widespread around the Tasmanian coast, although several species (for example the plants Gigartina ancistroclada Mont., Macrocystis pyrifera and Xiphophora gladiata and the fish Mendesoma.allporti Johnston) are absent from northern reefs. A large proportion of Maugean animals (viz. $42 \%$ of the fish species recorded in this study from the southern Tasmanian coast and Port Davey) and plants (e.g. Cystophora torulosa, Adenocystis utricularis (Bory) Skottsberg and Macrocystis pyrifera) also occur in similar latitudes in New Zealand. Many Peronian as.well as Maugean species are also common in New Zealand. However Flindersian species are notably absent. A considerable number of organisms thus appear to have dispersed across the Tasman Sea in recent times because
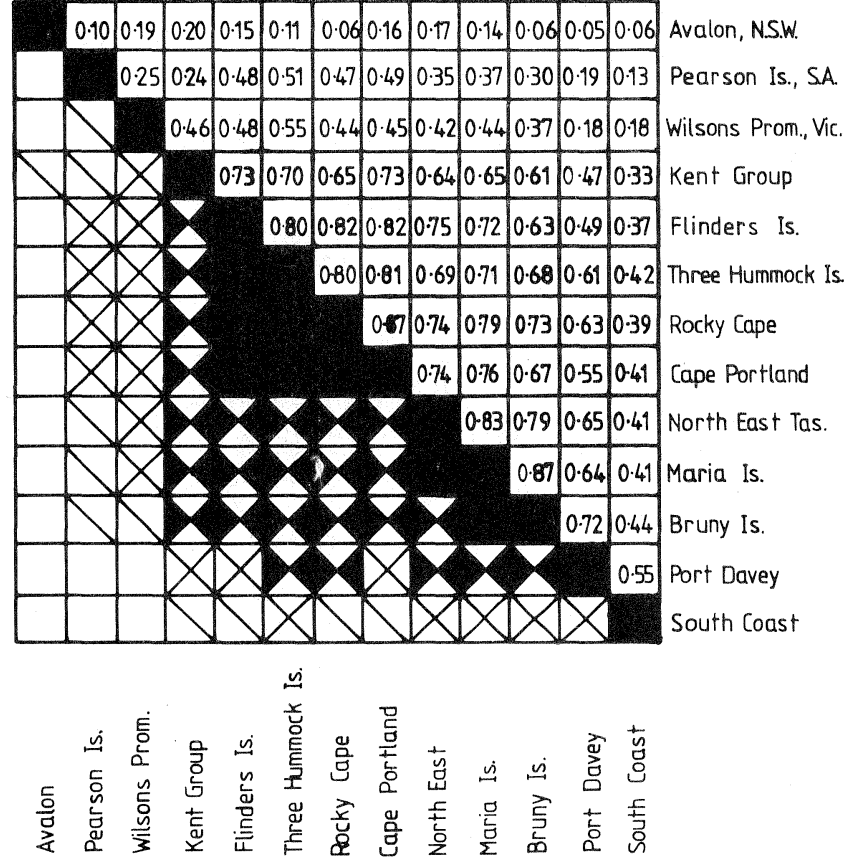

FIG. 4 - Matrix depicting the similarity of the noncryptic reef fish species which were sighted during the present survey between different regions of Tasmania and southeastern Australia. 
divergence and differentiation of isolated populations would be expected to have occurred during the period of more than 55 million years (Kennett 1977) since Australia separated from Gondwanaland. Recruitment of larval fish to New Zealand, presumably partly from Australia with assistance from the East Australian Current, was considered by Willan et al. (1979) to account for many of the tropical and subtropical fish species present in northern New Zealand.

Much of the disagreement about the merits of a Maugean biogeographic region has arisen because of the cool-temperate nature and low diversity of Tasmanian seas. At the northeastern study sites, for example, the number of Maugean fish species is comparable to the numbers of Flindersian and Peronian species. However, the Maugean species are represented by many more individuals and numerically dominate the ecosystems. Also, the Flindersian species at these sites comprise only a very small component of the total fauna in the Flindersian province while a large proportion of species in the Maugean province are represented.

Womersley's (1959) criticisms of the Maugean biogeographic province, which were based on the total marine flora of southern Australia, nevertheless still have some validity because differences between the temperate marine provinces become increasingly obscured with depth. Organisms within the intertidal zone and sublittoral fringe are much more localized in distribution than sublittoral and deeper water species (table 2). Few of the dominant subtidal benthic reef species in southern Tasmania are endemic to the Maugean region, and thus the cool-temperate marine province is not greatly distinctive if these organisms rather than reef fishes or intertidal species are considered.

In summary, providing differences rather than similarities between biogeographic regions are stressed, the shallow water biota in southern Tasmania is sufficiently distinctive to comprise a depauperate Maugean marine province. Many of the Maugean species have considerable dispersal ability, as is evident by their presence in New Zealand, but are restricted, presumably by water temperatures rather than biogeographic barriers, to the Tasmanian, Victorian and southeastern South Australian (to Cape Jaffa) regions in Australia. Conversely, Flindersian and Peronian species generally appear capable of dispersing to southern Tasmania but many of these species are unable to survive or reproduce within the region.

Dartnall (1974) suggested that the southern and eastern Australian biotas were isolated from each other during periods when Tasmania was connected by landbridge to the Australian mainland. This hypothesis is reinforced by the present study because the colder water temperatures during past ice ages would have allowed very few species to pass around the southern Tasmanian coast. Extant species pairs which presumably differentiated during such periods of isolation include the fish Arripis esper whitley/A. trutta (Bloch \&

Schneider), Upeneichthys lineatus (Bloch \& Schneider)/U. vlamingii (Cuvier \& Valenciennes), Paraplesiops meleagris (Peters)/P. bleekeri (Günther) and Scorpis aequipinnis Richardson/ $S$. Zineolatus Kner. Algae do not show similar sibling species pairs, however, and may require longer periods of isolation for the genetic divergence of isolated populations.

Past vicariant events (i.e. sea level changes resulting in Tasmania/Australia landbridges) thus appear to have separated the Flindersian and Peronian regions, resulting in allopatric speciation and allowing a high diversity of organisms in southern Australia to develop. The separation of the Maugean region, on the other hand, is probably due to water temperature and wave exposure barriers which operate at present on individual species.

\section{ACKNOWLEGEMENTS}

This research was made possible by the provision of diving equipment and logistic assistance by the National Parks and Wildlife Service and Zoology Department, University of Tasmania. A large number of people have given much needed help in the field during surveys of individual sites. These people include P.R. Last, P. Mooney, R.B. Mawbey, P.C. McGrath, J. Mason, M.W. Wells and R. Johnson. Thanks are also due to D.A. Ritz, S.A. Shepherd and P.R. Last for providing criticism of the manuscript. 


\title{
G.J. Edgar
}

TABLE 2

SPECIES FOUND ABUNDANTLY IN SOUTHERN TASMANIAN COASTAL WATERS BETWEEN SOUTH EAST CAPE AND SOUTH WEST CAPE.

F1ora

Fauna

\section{Eulittoral Species}

Gigartina ancistroclada* Lithophyllum hyperellum*

\author{
Littorina praetermissa* (May) \\ Cominella lineolatus* (Lamarck) \\ Notoacmaea mayi* May \\ Lepsiella vinosa* (Lamarck) \\ Siphonaria tasmanica* T-Woods \\ Siphonaria diemenensis* Quoy \& Gaimard \\ Patelloida Zatistrigata (Angas) \\ Cellana solida (Blainville) \\ Patelzanax peroni* (B1ainville) \\ Sypharochiton pelliserpentis (Quoy \& Gaimard) \\ Brachidontes rostratus* (Dunker) \\ Chamaesipho columna (Spengler) \\ Catomerus polymerus (Darwin) \\ Cyclograpsus granulosus* (M-Edwards)
}

Sublittoral Fringe and Rock Pool Species

$\begin{array}{ll}\text { Cystophora xiphocarpa* } & \text { Patiriella exigua (Lamarck) } \\ \text { Durvillaea potatorum* } & \text { Patelloida victoriana* (Singleton) } \\ \text { Xiphophora gladiata* } & \text { Poneroplax costata (Blainville) } \\ \text { Caulerpa brownii } & \text { Ischnochiton subviridus (Iredale \& May) } \\ & \text { Actinia tenebrosa Farquhar } \\ & \text { Naxia aurita (Latreille) } \\ & \text { Paragrapsus quadridentatus* (M-Edwards) }\end{array}$

Sublittoral Species ( $>5 \mathrm{~m}$ depth)

Cystophora platylobium

Phylzospora comosa

Ecklonia radiata

Macrocystis pyrifera*

Caulerpa brownii

Carpoglossum confluens

Melanthalia obtusata

Thamnoclonium clariferum

Lessonia corrugata*
Austrofromia polypora (Clark)

Petricia vemicina (Lamarck)

Nectria ocellata Perrier

Haliotis ruber Leach

Jasus novaehollandiae Hol thuis

Plagusia chabrus (Linnaeus)

Dicathais baileyana T-Woods

* Species very rarely if ever found within Australian waters outside Tasmania and the region from Robe, South Australia to Bermagui, N.S.W.

REFERENCES

Baines, P.G., Edwards, R.J. \& Fandry, C.B., 1983: Observations of a new baroclinic current along the western continental slope of Bass strait. Aust. J. Mar. Freshw. Res., 34: 155-157.

Bennett, I. \& Pope, E.C., 1960: Intertidal zonation of the exposed rocky shores of Tasmania and its relationship with the rest of Australia. Aust. J. Mar. Freshw. Res., 11: 182-221.

Cribb, A.B., 1954: The algal vegetation of Port Arthur, Tasmania. Pap. Proc. R. Soc. Tasm., 88: 1-44.

Dartnall, A.J., 1974: Littoral biogeography. In Williams, W.D. (Ed.): BIOGEOGRAPHY AND ECOLOGY IN TASMANIA. Junk, The Hague: 171-194. 
Dartnal1, A.J., 1981: THE ZOOGEOGRAPHY OF TASMANIAN SHALLOW WATER MARINE ZOOBENTHOS EXEMPLIFIED BY SOME CUMACEA. Unpub. Ph.D. thesis, University of Tasmania.

Davies, J.L., 1978: Beach sand and wave energy in Tasmania. In Davies, J.L. \& Williams, M.A.J. (Eds) : LANDFORM EVOLUTION IN AUSTRALIA. A.N.U. Press, Canberra: 158-167.

Department of Defense, 1977: Australia National Tide Tables 1978. Aust. Hydrogr. Pub. 11. Edgar, G.J., 1981: An initial survey of potential marine reserves in Tasmania. Nat. Parks Wildz. Serv. Occ. Pap., 4: 1-87.

, 1983a: The ecology of south-east Tasmanian phytal animal communities. I. Spatial organization on a local scale. J. Exp. Mar. Biol. Ecol., 70: 129-157. , 1983b: The ecology of south-east Tasmanian phytal animal communities. II. Seasonal change in plant and animal populations. eT. Exp. Mar. Biol. Ecol., 70: 159-179.

Edwards, R.J., 1979: Tasman and Coral sea ten year mean temperature and salinity fields. CSIRO Div. Fish. Oceanogr. Rep., No.88.

Godfrey, J.S., Jones, I.S.F., Maxwell, J.G.H. \& Scott, B.D., 1980: On the winter cascade from Bass strait into the Tasman Sea. Aust. J. Mar. Freshw. Res., 31: 275-286.

Guiler, E.R., 1952a: - The intertidal ecology of the Eaglehawk Neck area. Pap. Proc. R. Soc. Tasm., 86: 13-29.

, 1952b: The nature of intertidal zonation in Tasmania. Pap. Proc. R. Soc. Tasm., $86: 31-61$.

, 1954: The intertidal zonation at two places in southern Tasmania.

Pap. Proc. R. Soc. Tasm., 88: 105-118. , Serventy, D.L. \& Willis, E.H., 1958: The Fisher Island Field Station with an account of its principal fauna and flora. Pap. Proc. R. Soc. Tasm., 92: 165-183.

Iredale, T. \& May, W.L., 1916: Misnamed Tasmanian chitons. Proc. MaZac. Soc. Lond., $12: 94-117$

Kennett, J.P., 1977: Cenozoic evolution of Antarctic glaciation, the Circum-Antarctic Ocean, and their impact on global paleo-oceanography. J. Geophys. Res., 82: 3843-3860.

King, R.J., 1973: The distribution and zonation of intertidal organisms in Bass strait. Proc. R. Soc. Vict., 85: 145-163.

Last, P.R., 1983: ASPECTS OF THE ECOLOGY AND ZOOGEOGRAPHY OF FISHES FROM SOFT-BOTTOM HABITATS. Unpub. Ph.D. thesis, University of Tasmania.

Matthews, J., 1978: The sea-state of S.W. Tasmania. South West Tasm. Resources Survey Discussion Pap., 10: 1-43.

Newell, B.S., 1960: Hydrology of South East Australian waters. CSIRO Div. Fish. Oceanogr. Tech. Pap., No. 10.

Nilsson, C.S. \& Cresswe11, G.R., 1981: The formation and evolution of East Australian Current eddies. Progr. Oceanogr., 9: 133-183.

Nyan Taw, 1975: STUDIES OF THE ZOOPLANKTON AND HYDROLOGY OF SOUTH-EASTERN COASTAL WATERS OF TASMANIA. Unpub. Ph.D. thesis, University of Tasmania.

Pollock, R.A., 1971: A note on the tides in Bass Strait. Vict. Nat., 88: 148-152.

Rochford, D.J., 1974: The physical setting. In Banks, M.R. \& Dix, T.C. (Eds): RESOURCES OF THE SEA. ROY. SOC. Tasm., Hobart: 15-27.

1979: The nutrient status of the oceans around Australia. CSIRO Div. Fish. Oceanogr. Ann. Rep., 1977-1979: 9-20.

, 1981: Anomalously warm sea surface temperatures in the western Tasman Sea, their causes and effects upon the Southern Bluefin Tuna catch, 1966-1977. CSIRO Div. Fish. Oceconogr. Rep., 114: 1-19.

Saenger, P., 1974: Natural history of the Hogan Group - 2. Some marine algae from Hogan Island, Bass strait, with an account of the marine zonation. Pap. Proc. R. Soc. Tasm., 107: 73-81.

Santelices, B., Castilla, J.C., Cancino, J. \& Schmiede, P., 1980: Comparative ecology of Lessonia nigrescens and Durvilzaea antarctica (Phaeophyta) in Central Chile. Mar. Biol., 59: 119-132.

Shepherd, S.A. \& Womersley, H.B.S., 1970: The sublittoral ecology of West Island, South Australia. 1. Environmental features and the algal ecology. Trans. R. Soc. S. Aust., 94: 105-138. 


\section{G.J. Edgar}

Shepherd, S.A. \& Womersley, H.B.S., 1976: The subtidal algae and seagrass ecology of St Francis Island, South Australia. Trans. R. Soc. S. Aust., 100: 177-191. , 1981: The algal and seagrass ecology of Waterloo

Bay, South Australia. Aquatic Bot., 11: 305-371.

Southwood, T.R.E., 1966: ECOLOGICAL METHODS. Methuen, London: $391 \mathrm{pp}$.

Thomson, J.D., Sumner, C.E. \& Harris, J.G.K., 1982: Temperature and salinity records from an aquaculture monitoring program in Tasmania 1961-1981. Tasm. Fish. Dev. Auth. Rep. : $46 \mathrm{pp}$.

Willan, R.C., Dollimore, J.M. \& Nicholson, J., 1979: A survey of fish populations at Karikari Peninsula, Northland, by scuba diving. N.Z. J. Mar. Freshw. Res., 13: 447-458.

Womersley, H.B.S., 1959: The marine algae of Australia. Bot. Rev., 25: 545-614. , 1981: Marine ecology and zonation of temperate coasts. In Clayton, M.N. \& King, R.J. (Eds): MARINE BOTANY: AN AUSTRALASIAN PERSPECTIVE. Longman Cheshire, Melbourne: 210-240.

\& Edmonds, S.J., 1958: A general account of the intertidal ecology of South Australian coasts. Aust. J. Mar. Freshw. Res., 9: 217-260.

\section{APPENDIX 1}

NON-CRYPTIC REEF FISH SPECIES SIGHTED WITHIN VARIOUS INVESTIGATED REGIONS.

$\begin{array}{llll}\text { 1: Kent Group } & 5: \text { Cape Portland } & \text { 7: Maria Island } \\ \text { 2: Furneaux Group } & 6: \text { North East Coast } & 8: \text { Bruny Island } \\ \text { 3: Three Hummock Island } & \text { (Eddystone Point to } 9: \text { Port Davey } \\ \text { 4: Rocky Cape } & \text { Bicheno). } & \text { 10: South Coast }\end{array}$

\section{Species}

Heterodontus portusjacksoni (Meyer) Parascyzlium ferrugineum McCulloch* Cephaloscyliium Zaticeps (Dumeril)* Myliobatis australis Macleay Conger verreauxi Kaup* Lotelza rhacinus (Forster)

Pseudophycis bachus (Bloch \& Schneider)

Pseudophycis barbata Günther

Optivus elongatus Günther*

Paratrachichthys traili (Hutton)*

Cyttus australis (Richardson)*

Solegnathus spinossimus Günther*

Hippocampus abdominalis Lesson

Phyzloptemy taeniolatus Lacepede*

Helicolenus papizzosus (Bloch \& Schneider)*

Neosebastes scorpaenoides Guichenot*

Scorpaena ergastuZorum Richardson*

Gnathanacanthus goetzii Bleeker

Caesioperca Zepidoptera (Bloch \& Schneider)

Caesioperca rasor (Richardson)

Calzanthias alzporti Günther

Ellerkeldia macculzochi whitley

Hypoplectrodes nigrombrum Cuvier

Trachinops caudimaculatus McCoy*

Dinolestes Zewini (Griffith)

Vincentia conspersa (K1unzinger)

Pseudocaranx dentex Bloch \& Schneider

Seriolezza brama Günther

Trachurus declivus (Jenyns)

Arripis trutta (Bloch \& Schneider)

Region

$\begin{array}{llllllllll}1 & 2 & 3 & 4 & 5 & 6 & 7 & 8 & 9 & 10\end{array}$

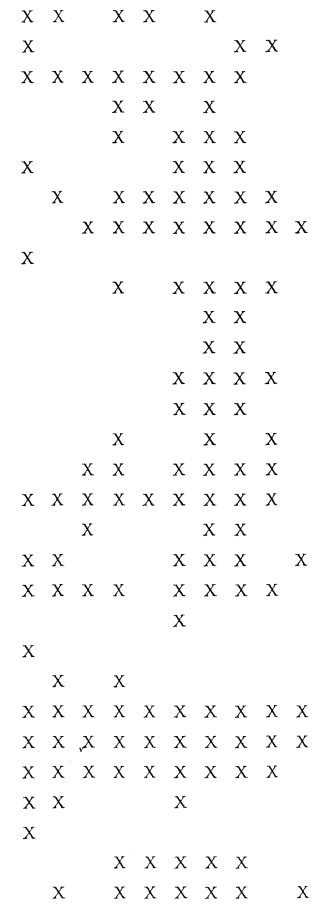




\section{Species}

Parequula melbournensis (Castelnau)

Upeneichthys vlamingii (Cuvier \& Valenciennes)* Parapriacanthus elongatus (McCulloch)

Pempheris multiradiatus Klunzinger

Girella elevata Macleay

Girella tricuspidata (Quoy \& Gaimard)

Melambaphes zebra (Richardson)

Scorpis aequipinnis Richardson

Scorpis lineolatus Kner

Atypichthys strigatus (Günther)

Enoplosus armatus (White)

Pentaceropsis recurvirostris (Richardson)

Chromis hypsilepis (Günther)

Parma microlepis Günther

Parma victoriae (Günther)

Chironemus marmoratus Günther

DactyZosargus arctidens (Richardson)*

Cheilodactylus nigripes Richardson

Cheilodactylus spectabilis (Hutton)*

DactyZophora nigricans (Richardson)

Nemadactylus macropterus (Bloch \& Schneider)*

Latridopsis forsteri (Castelnau)*

Latris lineata (Bloch \& Schneider)*

Mendesoma allporti Johnston*

Sphyraena novaehollandiae (Günther)

Dotalabrus aurantiacus (Castelnau)

Suezichthys sp.

opthalmolepis cyanogramma (Cuvier \& Valenciennes)

Pictilabrus laticlavius (Richardson)

Pseudolabrus fucicola (Richardson)*

Pseudolabrus psittaculus (Richardson)

Pseudolabrus tetricus (Richardson)

Heteroscarus acroptilus (Richardson)

Neoodax attenuatus (Ogilby)

Neoodax balteatus (Cuvier \& Valenciennes)*

Neoodax beddomei (Johnston)

Olisthops cyanomelas Richardson

Siphonognathus argyrophanes (Richardson)

Bovichthys variegatus (Quoy \& Gaimard) *

Acanthaluteres spilomelanurus (Quoy \& Gaimard)

Brachaluteres jacksonianus (Quoy \& Gaimard)

Eubalichthys gunni (Günther)

Eubalichthys mosaicus (Ramsay \& Ogilby)

Meuschenia australis (Donovan)*

Meuschenia flavolineata Hutchins

Meuschenia freycineti (Quoy \& Gaimard)

Meuschenia hippocrepis (Quoy \& Gaimard)

Parika scaber (Günther)

Penicipelta vittiger (Castelnau)

Aracana aurita (Shaw)

Aracana ornata (Gray)

Diodon nichthemerus (Cuvier)
Region

$\begin{array}{llllllllll}1 & 2 & 3 & 4 & 5 & 6 & 7 & 8 & 9 & 10\end{array}$

$\begin{array}{llllllll}x & x & x & x & x & x & x & x\end{array}$

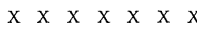

$\begin{array}{lll}x & x\end{array}$

$\begin{array}{lllllllll}x & x & x & x & x & x & x & x & x\end{array}$

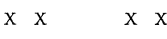

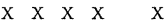

$\begin{array}{llllll}x & x & x & x & x & x\end{array}$

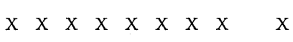

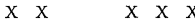

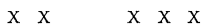

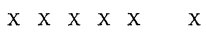

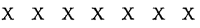

$\mathrm{x}$

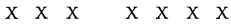

$\begin{array}{llllll}x & x & x & x & x\end{array}$

$x$

$x$

$\begin{array}{llllllllll}x & x & x & x & x & x & x & x & x & x\end{array}$

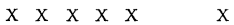

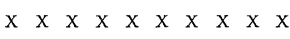

$x \quad x$

$\begin{array}{llll}x & x & x & x\end{array}$

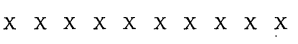

$x \quad x$

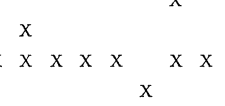

$\begin{array}{lllllllll}x & x & x & x & x & x & x & x & x\end{array}$

$\begin{array}{llllllllll}x & x & x & x & x & x & x & x & x & x\end{array}$

$\begin{array}{llllllllll}x & x & x & x & x & x & x & x & x & x\end{array}$

$\begin{array}{lllllllll}x & x & x & x & x & x & x & x & x\end{array}$

$x \quad x \quad x \quad x \quad x$

$x$

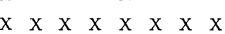

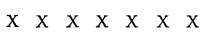

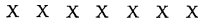

$x$

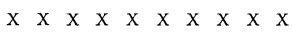

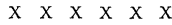

$\begin{array}{lllllllllllllllll}x & x & x & x\end{array}$

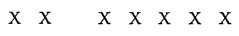

$\begin{array}{lllllllll}x & x & x & x & x & x & x & x & x\end{array}$

$x \quad x$

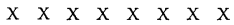

$x \quad x \quad x$

$\mathrm{x}$

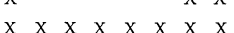

$\begin{array}{lllllllll}x & x & x & x & x & x & x & x & x\end{array}$

$\begin{array}{llllll}x & x & x & x & x\end{array}$

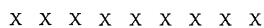

* Cool-temperate species. 